\title{
Collaborative stewardship in multifunctional landscapes: toward relational, pluralistic approaches
}

\author{
Jessica Cockburn ${ }^{1}$, Georgina Cundill ${ }^{2}$, Sheona Shackleton ${ }^{3,4}$, Mathieu Rouget $^{5}$, Marijn Zwinkels $^{6}$, Susanna (Ancia) Cornelius $^{7}$, Liz

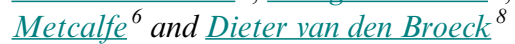

\begin{abstract}
Landscape stewardship offers a means to put social-ecological approaches to stewardship into practice. The growing interest in landscape stewardship has led to a focus on multistakeholder collaboration. Although there is a significant body of literature on collaborative management and governance of natural resources, the particular challenges posed by multifunctional landscapes, in which there are often contested interests, require closer attention. We present a case study from South Africa to investigate how collaborative stewardship can be fostered in contested multifunctional landscapes. We conducted this research through an engaged transdisciplinary research partnership in which we integrated social-ecological practitioner and academic knowledge to gain an indepth understanding of the challenges of fostering collaboration. We identified five overarching factors that influence collaboration: contextual, institutional, social-relational, individual, and political-historical. Collaborative stewardship approaches focused on the development of formal governance institutions appear to be most successful if enabling individual and social-relational conditions are in place. Our case study, characterized by high social diversity, inequity, and contestation, suggests that consensus-driven approaches to collaboration are unlikely to result in equitable and sustainable landscape stewardship in such contexts. We therefore suggest an approach that focuses on enhancing individual and social-relational enablers. Moreover, we propose a bottom-up patchwork approach to collaborative stewardship premised on the notion of pluralism. This would focus on building new interpersonal relationships and collaborative capacity through small collective actions. Taking a relational, pluralistic approach to fostering collaborative stewardship is particularly important in contested, socially heterogeneous landscapes. Drawing on our study and the literature, we propose guiding principles for implementing relational, pluralistic approaches to collaborative stewardship and suggest future research directions for supporting such approaches.
\end{abstract}

Key Words: environmental stewardship; equity; multifunctional landscapes; multistakeholder collaboration; social-ecological systems; South Africa; sustainability; transdisciplinary research.

\section{INTRODUCTION}

The notion of stewardship has recently received renewed attention in response to rising concerns about social-ecological sustainability challenges (Folke et al. 2016). This is evidenced in the rapid growth in work conceptualizing stewardship (Bennett et al. 2018, Mathevet et al. 2018, Peçanha Enqvist et al. 2018) especially in the social-ecological systems and resilience literature, in which stewardship is framed as a necessary response of humanity in an era of rapid environmental change (Chapin et al. 2009, Cockburn et al. 2019a). Emerging from this literature is a growing recognition that, although planetary-level stewardship is certainly needed (Steffen et al. 2011), supporting local place-based stewardship activities is as critical (Balvanera et al. 2017).

Multifunctional landscapes provide a suitable place-based unit for addressing complex sustainability concerns including stewardship (Cockburn et al. 2018, 2019a). Multifunctional landscapes are landscapes that provide a diversity of ecosystem functions or services that underpin social and economic functioning for a range of beneficiaries or landscape stakeholders (Minang et al. 2014a). The benefits of ecosystem services in multifunctional landscapes (compared to monofunctional landscapes), are often experienced more locally, and local people are therefore more likely to engage in stewardship and participate in landscape management (Fischer et al. 2017). Consequently, the notion of landscape stewardship has arisen as a means of putting stewardship into practice in a tangible, place-based, and actionoriented way toward sustainable multifunctional landscapes (Bieling and Plieninger 2017, Cockburn et al. 2018).

The "landscape level" is a spatial scale above the field, farm, and local village level at which the actions and decisions of individual farmers or local resource-user groups intersect with those of other resource users, stakeholders, and decision makers (Frost et al. 2006, Prager et al. 2012). The boundaries of landscapes can be defined in many ways, for example, by using biophysical catchment boundaries, institutional or jurisdictional boundaries, or the boundaries of an area with a unique or coherent character as understood by local inhabitants (Prager et al. 2012). We use the latter means of defining landscape boundaries in this study. Working at the landscape level requires moving beyond the interests of individual stakeholders or small interest groups at a more local level (e.g., farm or village), toward a more holistic, collaborative approach to stewarding landscapes (Cockburn et al. 2018).

At the landscape level, this means that the interests of multiple stakeholders need to be negotiated and managed in an integrated manner to reduce contestation related to sharing the costs and benefits of landscape resources (Floress et al. 2018). A focus on multistakeholder collaboration and collaborative stewardship has thus emerged as a key opportunity but also a challenge for

\footnotetext{
${ }^{1}$ Environmental Learning Research Centre, Department of Education, Rhodes University, Makhanda (Grahamstown), South Africa, ${ }^{2}$ International Development Research Centre, Ottawa, Canada, ${ }^{3}$ Department of Environmental Science, Rhodes University, Grahamstown, South Africa, ${ }^{4}$ African Climate and Development Initiative, University of Cape Town, South Africa, ${ }^{5}$ UMR PVBMT, CIRAD, St. Pierre, La Réunion, France, ${ }^{6}$ Living Lands, Cape Town, South Africa, ${ }^{7}$ Living Lands, Twee Riviere, South Africa, ${ }^{8}$ Commonland, Amsterdam, The Netherlands
} 
sustainable and equitable landscape stewardship (Prager et al. 2012, Penker 2017). In multifunctional landscapes with a wide range of stakeholders with multiple different interests, collaborative processes therefore become more complex (Cockburn et al. 2018), and a wide range of factors influence multistakeholder collaboration (Margerum and Robinson 2016a, Ayala-Orozco et al. 2018).

In this study, we conceptualize collaboration in two ways. First, in a broad sense, we draw on Gray's (1985:912) definition of collaboration as "the pooling of appreciations and/or tangible resources, e.g., information, money, labor, etc., by two or more stakeholders, to solve a set of problems which neither can solve individually." In this sense, we use the word "collaboration" to mean the working together of stakeholders in the landscape in a general way that includes working together for stewardship or landscape management, but can also include working together for other purposes such as farming, community development, or recreation. Second, in a more specific sense, we use the concept of collaborative stewardship. This we define as a collective process involving multiple, diverse resource users in the landscape who act together and share risks, resources, and responsibilities to take care of natural resources and achieve the ideals of stewardship in practice (Ayala-Orozco et al. 2018, Cockburn et al. 2018). Our premise is that an understanding of collaboration in the landscape, in the broad sense (not only for stewardship), will give insights to the factors that influence the ability of multiple stakeholders to work together specifically for collaborative stewardship.

The literature on collaboration for natural resource management and landscape stewardship discusses a wide range of factors that influence collaborative processes (Ostrom 1990, Wondolleck and Yaffee 2000, Armitage et al. 2007a, Margerum and Robinson $2016 a$ ). Some of these factors refer to structural aspects of collaboration, whereas others refer to relational aspects (Patterson 2017). The enduring focus on institutions and governance mechanisms for collaboration, i.e., a focus on bureaucratic forms of collaboration (Cleaver 2002), has resulted in an emphasis on putting in place structural enablers for collaboration, e.g., institutional design principles (Ostrom 2005, Poteete et al. 2010)). Somewhat less focus has been placed on the nuances of social-relational processes that underpin effective collaboration (Cockburn et al. 2018), although research on social networks is beginning to address this (Bodin and Crona 2009, Alexander and Armitage 2015).

Structural factors that influence collaboration include policy mechanisms and formal institutional arrangements, which can facilitate power sharing, negotiation, and conflict resolution (Armitage et al. 2007b, Ostrom and Cox 2010). Such formal institutions often focus on developing processes that lead stakeholders toward consensus on how natural resources should be managed (Ansell and Gash 2007, Margerum and Robinson 2016b). Moreover, institutions in the form of formal agreements that provide incentives or contribute to costs of stewardship actions can also provide a sense of security for stewards expected to invest resources to change their farming practices (Church and Prokopy 2017). Structural conditions at a national level also influence how collaboration plays out, particularly in contexts of eroding formal governance and limited statehood (Ayala-Orozco et al. 2018).
Relational factors, which influence collaboration, are often analyzed through the notion of social networks (Bodin and Crona 2009) or through understanding the social, cultural, political, and historical embeddedness of collaboration (Cleaver 2002). Social networks for landscape stewardship are dependent on longstanding social relationships and good will (Patterson 2017), which build social capital over time (Alexander and Armitage 2015). Social capital is concerned with the cohesiveness of a social network, based on the existence of reciprocal relational ties among actors in a social network (Crona et al. 2011). Trust between stakeholders is often considered a key ingredient in the development of social capital and social networks, and is possibly one of the most widely cited yet elusive enablers of collaboration (Hahn et al. 2006, Armitage et al. 2007b). Individual human agency, i.e., how humans relate to their inner selves and to society, and how they act, is a key enabler of collaborative processes. Individual agency is often focused on through the notion of leadership in collaborative processes (Bodin 2017) or individual stewardship ethic in landscape stewardship (Welchman 2012). The interactions between individual and collective agency, often mediated by power relations, also play an important role in how collaborative processes unfold (Cleaver 2007).

Although this outline suggests that much knowledge has been generated on the factors influencing collaboration, the studies cited are not necessarily from cases of collaboration in contested contexts such as multifunctional landscapes (Cockburn et al. 2018). There is also limited literature on building collaboration in the Global South and in contexts of weak or eroding governance (but see Ayala-Orozco et al. 2018). Furthermore, there is limited qualitative, place-based research that seeks to understand the nuances of social and contextual factors affecting collaborative relationships in multifunctional landscapes (Zachrisson and Beland Lindahl 2013, Cockburn et al. 2018). Therefore, although we recognize the existing literature on collaboration as an important source of knowledge on collaboration, we purposefully took a situated, grounded, and inductive approach to investigating collaboration in our case, not drawing directly on any one specific framework from existing literature in our analysis.

The purpose of our study is to investigate how collaborative stewardship can be fostered in contested multifunctional landscapes, using the Langkloof region in South Africa as a case study. Our research objectives were to: (1) identify existing collaborative initiatives in the landscape (examples of both collaboration in general and collaborative stewardship specifically), and (2) analyze factors that influence collaboration and collaborative stewardship by identifying enablers and barriers of collaboration.

\section{THE LANGKLOOF CASE STUDY}

The Langkloof region stretches across the Kouga and Krom river catchment areas $\left( \pm 400 \mathrm{~km}^{2}\right)$ in the Eastern Cape province of South Africa (Fig. 1; Swiegers 1994, van Huyssteen 2008). The name "Langkloof" (long valley) refers to a social-geographic boundary and does not align directly with either the catchment boundaries or municipal jurisdictions but is well-understood by residents (Mulkerrins 2015). 
Fig. 1. Map of the Langkloof region indicating different agricultural subcommunities, primary land-use activities, and towns or villages. Each colored patch on the map indicates a different subcommunity. Note: information generated from interviews.

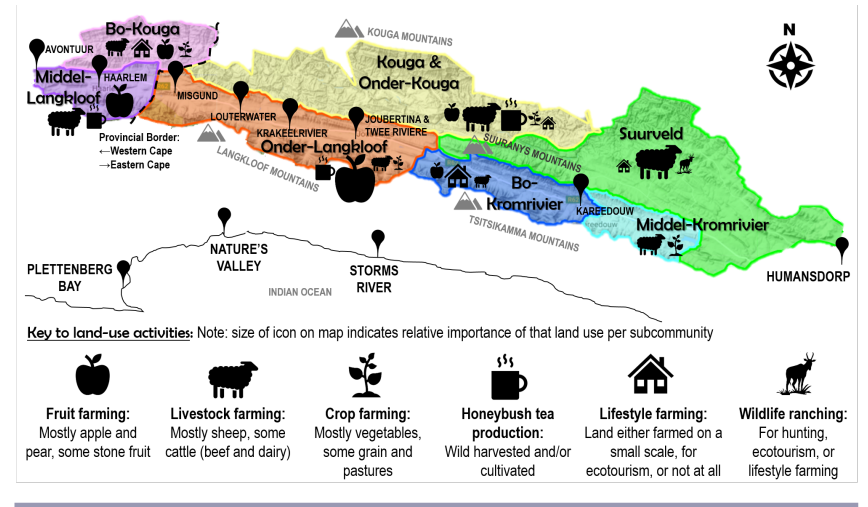

History of social-ecological change in the landscape

The history of interactions between humans and the landscape in the Langkloof region can be divided into three periods: Period 1 (pre-1760: precolonial era), Period 2 (from 1760 to 1994: colonial and Apartheid era), and Period 3 (from 1994 until the present: the democratic era; Table 1; du Toit 1931, Guelke and Shell 1992, Swiegers 1994, Ross 1997, Beinart 2000, van Huyssteen 2008, Hamann and Tuinder 2012, de Laat 2017) ${ }^{[1]}$. During these three periods, environmental values and the proportional use of ecosystem services by different social groups shifted alongside social-political changes in the landscape (Table 1).

Over time, increasing agricultural commercialization and productivity in the Langkloof has been accompanied by increasing social inequality. This must be understood against the backdrop of colonial and Apartheid era dispossession of nonwhite residents from the land. Despite some efforts to shift land-ownership patterns from mostly white ownership through land reform initiatives (Kou-Kamma Local Municipality 2009, Schafer 2014), the benefits of natural resources are not yet being shared equitably among the residents of the Langkloof, which may explain the social-political tensions in the landscape (Mulkerrins 2015, de Laat 2017). Nonetheless, commercial farming activities in the Langkloof are considered an important economic activity for the region, providing employment and bringing in foreign exchange (Schafer 2014).

\section{Current landscape situation: multifunctionality and stewardship challenges}

The Langkloof is a multifunctional landscape (Fig. 2). The five primary functions of the landscape are: agriculture, water use and storage, biodiversity conservation, tourism, and residential areas (Veerkamp 2013). Farming activities include crop and fruit farming, wild harvesting and cultivation of indigenous honeybush tea, which grows in the fynbos vegetation (Cyclopia spp.; Joubert et al. 2011), and livestock farming (Fig. 1). The area has high biodiversity value (Mander et al. 2010, McClure 2012). Much of the biodiversity is protected through formal protected areas; however, biodiversity is still regarded as being under threat (Mander et al. 2010).
Fig. 2. Scenes from the Langkloof region: A: View of the Langkloof from the highest peak in the Langkloof mountain range (Formosa Peak), looking north-west toward the settlement of Louterwater. Each oval indicates a specific land use or function in the landscape, thus the Langkloof can be considered a multifunctional landscape. B: These apples were given to the lead author by one of the successful emerging farmers in the Langkloof (see vignette 1, Table 3). C: Members of the Living Lands team discussing river bank erosion with a Langkloof farmer. Historical Soil Conservation Committees played an important support and oversight function for natural resource management on private commercial farms (see vignette 2, Table 3). D: Suurveld farmers are sheep and cattle farmers. They have a strong sense of pride in their identity as stock farmers (see vignette 3 , Table 3 ).

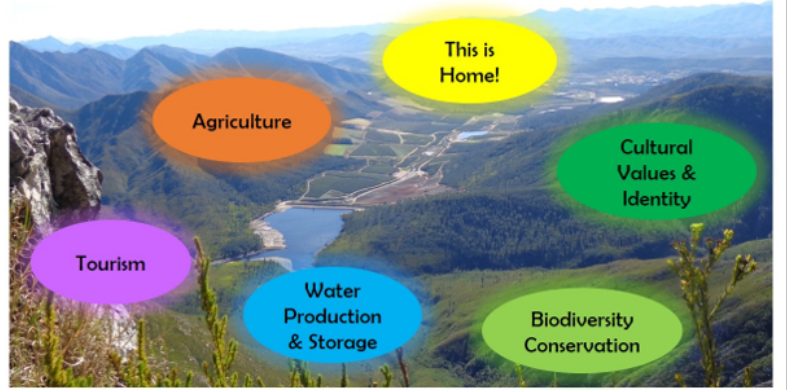

A: The Langkloof is a multifunctional landscape.

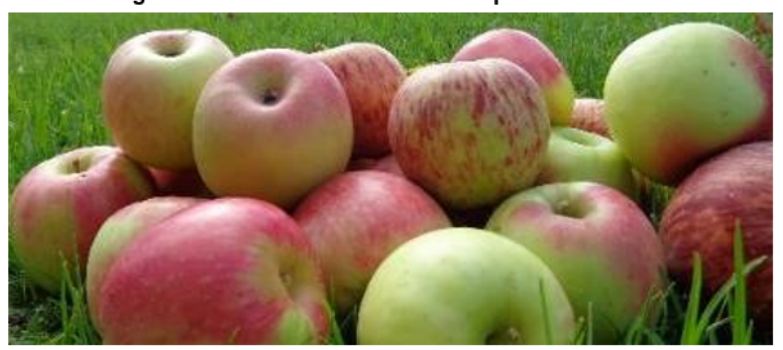

B: Apples produced by successful emerging farmers in the Langkloof.

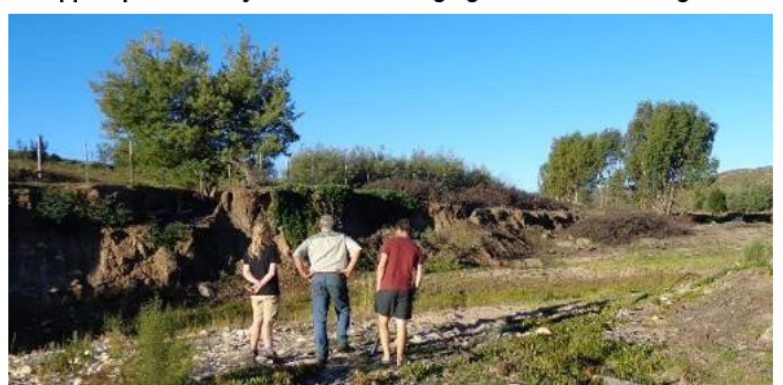

C: Living Lands team visiting a farmer to discuss restoration activities.

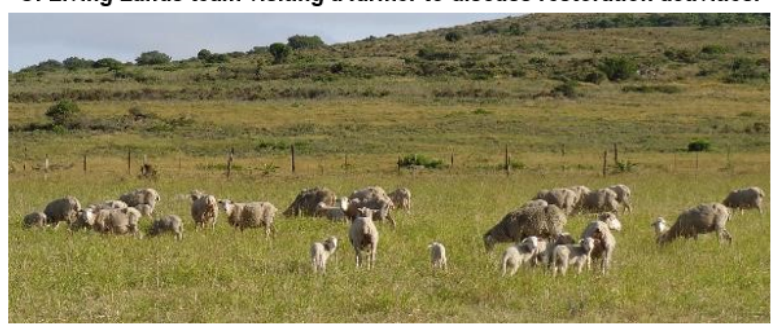

D: The Suurveld is a unique agricultural subregion in the region. 
Table 1. Historical timeline of social-ecological change in the Langkloof, based on a review of background documents and literature (du Toit 1931, Guelke and Shell 1992, Swiegers 1994, Ross 1997, Beinart 2000, van Huyssteen 2008, Hamann and Tuinder 2012, de Laat 2017).

\begin{tabular}{|c|c|c|c|}
\hline What has changed? & $\begin{array}{l}\text { Pre-1760: } \\
\text { Precolonial era }\end{array}$ & $\begin{array}{l}\text { 1760-1990s } \\
\text { Colonial and Apartheid era }\end{array}$ & $\begin{array}{l}\text { Post-1994 } \\
\text { Current democratic era }\end{array}$ \\
\hline $\begin{array}{l}\text { Human population: } \\
\text { Who lives in the } \\
\text { Langkloof? }\end{array}$ & $\begin{array}{l}\text { Nomadic San and } \\
\text { Khoikhoi }\end{array}$ & $\begin{array}{l}\text { Primarily Dutch (white) settler farmers, } \\
\text { initially some San and Khoi but they } \\
\text { were eventually dispossessed of land } \\
\text { and pushed out, some became laborers } \\
\text { on farms. }\end{array}$ & $\begin{array}{l}\text { Mixed population. On farms: mostly white farmers and } \\
\text { mixed race or black laborers (a few mixed race and black } \\
\text { farmers); in towns: white, middle class residents in } \\
\text { suburbs, mostly mixed race and black working class or } \\
\text { unemployed residents in "townships". New people } \\
\text { arriving from outside the landscape known as } \\
\text { "inkommers" (incomers). }\end{array}$ \\
\hline $\begin{array}{l}\text { Politics and } \\
\text { governance: } \\
\text { Who has power and } \\
\text { control over decisions? }\end{array}$ & $\begin{array}{l}\text { Localized power and } \\
\text { decision making within } \\
\text { small clans or groups; } \\
\text { leaders were mostly men. }\end{array}$ & $\begin{array}{l}\text { Colonial era: colonial authorities } \\
\text { (Dutch and British), through regional } \\
\text { magistrates. Apartheid era: } \\
\text { authoritarian white minority } \\
\text { government: national, provincial, and } \\
\text { local. }\end{array}$ & $\begin{array}{l}\text { Democratic, pluralist governance model at national, } \\
\text { provincial, and local level. Strong emphasis on neoliberal } \\
\text { economic policies: markets and economic drivers are also } \\
\text { powerful. Land and water reforms are legislated to } \\
\text { redistribute rights and access. }\end{array}$ \\
\hline
\end{tabular}

Society's environmental values: What values inform interactions with nature?

Land and natural resource use: How are land and natural resources used?

Strong spiritual and subsistence ties to nature, strong emphasis on respecting all of nature, living off the land "as it is." Wildlife hunting, gathering of natural resources, livestock grazing, drinking water, all for subsistence use, for collective use and benefit.

Responsibility for and control over natural resources:

Who are the stewards?

Ecosystem function and biodiversity
Nomadic San (mostly hunter-gatherers) and Khoikhoi (mostly herders, but also hunter-gatherers)

Near-pristine state: possibly some grazing and hunting impacts, high biodiversity. local.

Dualist environmental values strongly influenced by the Christianity and colonial ambitions to "conquer" the land

Initially, livestock and mixed crop farming, primarily for subsistence use, and later commercial agricultural production for profit (livestock, crops, fruit); reliance on irrigation infrastructure for water abstraction and storage, for private use and benefit. Nature reserves declared in early to mid- $20^{\text {th }}$ century.

Primarily Dutch (white) settler farmers; Mostly white farmers, a few mixed race and black later some policies to regulate land-use decisions and practices to promote responsible use.

Due to agricultural impacts and invasive alien species, ecosystem function begins to deteriorate, some biodiversity lost due to clearing of vegetation for farming.
Environmental values based on sustainability; consideration for the needs of future generations; these values are in conflict with the dominant economic practice of extractivist profit-making informed by neoliberal economic policy.

Commercial agricultural production of deciduous fruit, much of it for export markets. Some mixed farming (crops and livestock) for local markets, increasing reliance on irrigation infrastructure for water abstraction and storage, for private use and benefit. Tourism emerges as an important socioeconomic activity. farmers; policy to regulate land use to promote responsible use; and policy for regulation of control and access to natural resources (land, water), though policy implementation is inconsistent.

Ecosystem function is impaired, some biodiversity loss (terrestrial and aquatic), ongoing degradation of hydrological systems is a concern, however ecological restoration interventions are being implemented, e.g., Working for Water and related initiatives

Townships are residential areas usually on the edge of town, which were historically set aside for black and mixed race people during the Apartheid era. This spatial, racial segregation persists even into the democratic era.>

To gain an understanding of the Langkloof context, it is necessary to consider influences beyond the local landscape level. The Langkloof falls within the Kouga and Krom catchments, which produce almost $70 \%$ of the water supply for the city of Port Elizabeth, which lies outside the landscape (Mander et al. 2010, Talbot 2012). Simultaneously, water availability is a primary determinant of the local agricultural economy (Schafer 2014, de Kock 2015). This multilevel, multifunctional use of the landscape highlights potential trade-offs among multiple ecosystem services in the landscape, emphasizing the importance of collaborative stewardship and the potential challenges toward achieving this.

There are a variety of stewardship challenges in the Langkloof, including catchment management (water quality and quantity concerns), soil management, invasive alien species management, fire management, unsustainable farming practices, and biodiversity conservation (Mander et al. 2010, McClure 2012, Rebelo et al. 2013, Veerkamp 2013, van de Witte 2015). Overall, concerns related to water supply and catchment management are considered the most important of these challenges by many stakeholders (Mander et al. 2010, de Jong 2012, Talbot 2012, Veerkamp 2013).

In working toward stewardship of the multifunctional Langkloof landscape, the inequitable sharing of ecosystem services and benefits from the landscape cannot be ignored. Some of the most pressing social issues include unequal access to land and water, unequal sharing in the benefits of agriculture, and a gender bias in agriculture (Kou-Kamma Local Municipality 2012, de Laat 2017; Table 1). Social-ecological heterogeneity, social-political contestation and the large scale of the landscape pose significant challenges to efforts to facilitate collaborative stewardship in the landscape (Veerkamp 2013, Mulkerrins 2015, de Laat 2017).

\section{METHODS}

We conducted this research through an engaged transdisciplinary research partnership (Lang et al. 2012). This is a knowledge 
production process integrating practice-based (Weber et al. 2014) and academic knowledge (across various social and ecological disciplines) to gain an in-depth understanding of the challenges of fostering collaborative stewardship. We did this by partnering with the organization Living Lands working in the Langkloof (Living Lands 2017). The lead author was embedded in Living Lands from January 2015 to December 2017 (See Box 1 for an overview of Living Lands, see also Cockburn 2018).

This study is an inductive, qualitative case study in which multiple sources of data were analyzed in an integrated manner to develop a contextual, situated understanding of the case (Yin 2009, Maxwell 2012; Fig. 3). We generated qualitative data to construct the case study and gather findings from stakeholder interviews, participant observation, and collective reflections with the Living Lands team. Background documents were used as a source of secondary data (Fig. 3). The lead author conducted face-to-face, semistructured interviews with landscape stakeholders $(n=68)$ from February to August 2016. Interviews centred on five main themes and were conducted in a conversational manner, allowing for other topics to emerge in conversation: (1) your story in the Langkloof (history, origins, community); (2) important natural resources (ecosystem services) in the Langkloof; (3) stewardship or sustainability actions; (4) collaboration (for natural resource management and other issues); and (5) sustainability or stewardship challenges in the landscape (see interview guide in Appendix 1).

Fig. 3. Qualitative data generation and analysis methods for the Langkloof case study. Data were generated for two main purposes: 1 . To generate a landscape overview (case description), and 2. To gain an in-depth understanding of collaboration in the landscape.

\section{LANDSCAPE OVERVIEW:}

Historical timeline: describe social-ecological change over time

Social-ecological inventory: describe features of the current landscape

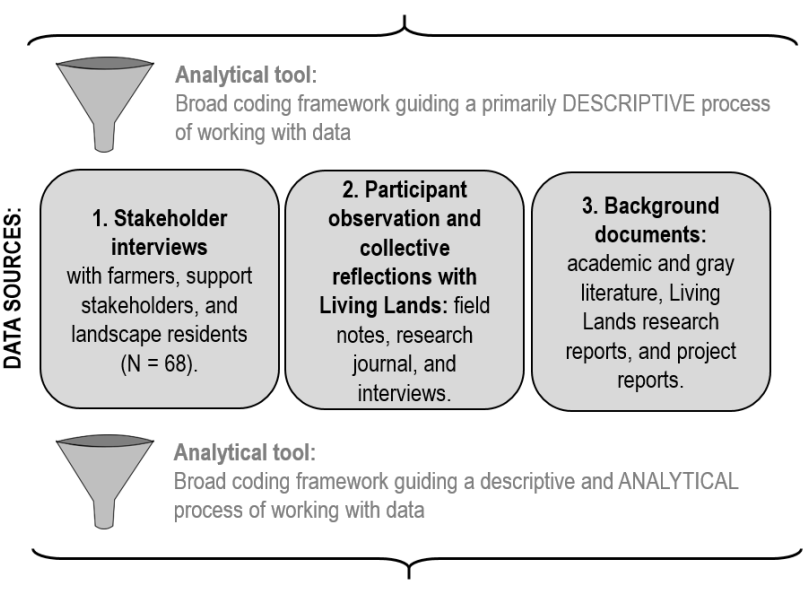

\section{UNDERSTANDING COLLABORATION:}

Identify existing collaborative initiatives and attempts from all data sources Identify enablers and barriers of collaboration quantitatively from interview data

Develop vignettes to illustrate enablers and barriers qualitatively and contextually (from all data sources)
Sampling and participant recruitment for interviews was based on purposive snowball sampling (Sadler et al. 2010) with a view to a sample that covered the geographic and demographic diversity of the landscape. Interview respondents were either stewards (i.e., farmers: agricultural land owners or users), support stakeholders (people who play a role in supporting agriculture, conservation, or natural resource management), or nonfarming local residents. The sample of farmers was broadly stratified by geographical location, land-use type, and race. Interviews were audio recorded when participants consented and were fully transcribed.

Participant observation (by the lead author) took place opportunistically over a two-year period from March 2015 to April 2017. This included active involvement in 6 field trips, 3 stakeholder workshops, 12 project meetings, and 6 research feedback meetings with the Living Lands team. In parallel, we conducted on-going reflection sessions within the broader Living Lands team in the landscape. Additional data were collected via background documents about the region sourced from the internet, the local university, and Living Land's own databases (primarily used to construct the landscape overview and Box 1).

Data analysis followed an inductive, iterative, and integrative process of coding and analyzing the qualitative data from multiple sources (Bazeley 2012, Maxwell 2012), with an initial focus on the interview data, followed by additional supporting data sources (Fig. 3). We used NVivo software for transcription, data management, and analysis (QSR International 2017).

Research ethics approval was granted by Rhodes University (Department of Environmental Science Ethics Subcommittee, August 2015). Feedback was provided to research participants via email, and informally via interactions with the Living Lands team in the Langkloof.

Box 1:

\section{Overview of Living Lands activities in the Langkloof region}

Living Lands is a nonprofit organization working in the Langkloof region with local farmers and other relevant stakeholders to bring about sustainable natural resource management across the landscape according to their vision of collaborations working on living landscapes (Talbot 2012, Living Lands 2017), i.e., they are facilitating collaborative stewardship (Figs. 1, 2). Living Lands strives to take a "living landscape approach" in their work, which focuses on maintaining a longterm presence in the local community, serving the needs of the landscape, and identifying project funding opportunities that can support a broader vision for building sustainability in the landscape. They work according to the "four returns" model, which seeks to bring about a return of financial capital, natural capital, social capital, and inspiration (Brasser and Ferwerda 2015; for further information on the work of Living Lands see their website at www.livinglands.co.za).

Living Lands' experiences of facilitating collaborative stewardship

Living Lands has actively been facilitating collaborative stewardship in the Langkloof since 2011, partnering with various organizations in the process. However, progress toward achieving its vision has been somewhat slow and difficult. It has been 
Table 2. Existing and recently existing $\dagger$ collaborative initiatives in the Langkloof region. Note: this is not intended to be an exhaustive list.

\begin{tabular}{|c|c|}
\hline Bureaucratic (Formal) Collaborative Initiatives & Socially Embedded (Informal) Collaborative Initiatives: \\
\hline \multicolumn{2}{|c|}{ Collaborative stewardship (collaborative conservation and natural resource management initiatives): } \\
\hline Disaster Risk Management Advisory Forum ${ }^{\S}$ & Fire-fighting, management, and prevention ${ }^{\S}$ \\
\hline Fire protection associations $\$$ & Hunting problem animals \\
\hline Irrigation boards $s^{\S}$ & Natural disasters like fire, floods, and droughts ${ }^{\S}$ \\
\hline Conservancies $\$$ & Sharing water ${ }^{\S}$ \\
\hline Baviaanskloof Mega-Reserve Steering Committee ${ }^{\S}$ & Krom River Catchment Initiative ${ }^{\S}$ \\
\hline Eden-to-Addo Corridor Initiative & Language of the Wilderness Foundation workshops and activities (NGO) \\
\hline Formosa Forum & Living Lands workshops and activities (NPO) \\
\hline \multicolumn{2}{|l|}{ Collaboration for the business of farming: } \\
\hline Farmers' associations: Langkloof, Suurveld, Avontuur & Fruit storage, packing, marketing, and transport \\
\hline Koukamma Emerging Farmers Task Team & Road maintenance \\
\hline Black Economic Empowerment Joint Farming Ventures & Sharing implements and equipment \\
\hline Area-wide integrated pest management & Sharing knowledge \\
\hline Agricultural co-op stores, e.g., Humansdorp Co-op & Sharing labor \\
\hline Granor Passi juice factory & Labor wage negotiations \\
\hline \multirow[t]{2}{*}{ Honeybush tea harvesting co-operatives } & Livestock auctions \\
\hline & Agronomy study groups \\
\hline \multicolumn{2}{|l|}{ Collaboration for community and social life: } \\
\hline Haarlem Women's Forum & Informal women's groups \\
\hline Various community security initiatives & Schools and churches \\
\hline Tourism Associations & Sports and social clubs and events \\
\hline \multicolumn{2}{|c|}{$\begin{array}{l}\text { + Bureaucratic collaborative initiatives are formalized arrangements based on explicit organizational structures, contracts, and legal } \\
\text { rights, whereas socially embedded collaborative initiatives are based on culture, social organization, interpersonal relationships, and } \\
\text { daily practice (Cleaver 2002). }\end{array}$} \\
\hline
\end{tabular}

particularly difficult to build meaningful relationships with, and collaborative stewardship among, large-scale commercial farmers, who are eager to see tangible benefits of collaborating in the short term. Consequently, Living Lands has shifted focus to engage with a range of smaller-scale or family-managed farmers who seem more open to collaboration and trying out innovative stewardship practices, i.e., they have a shared interest in the collaborative stewardship approaches that Living Lands are championing.

Despite the diversity of stakeholders in the Langkloof, there is a sense that many share a similar vision for the future of the Langkloof (Draugelyte 2012). There is, for example, a strong shared sense of place and identity as Langkloofers, despite many other differences. The wish of many stakeholders is for better relationships, for a move away from the current situation of antagonism and conflict toward improved cooperation, and an improved quality of life for all residents (Mulkerrins 2015).

However, student research conducted through Living Lands has shown that there are high levels of suspicion, resentment, and mistrust among various stakeholder groups. There are deep divisions between people of different race groups, and there is a lack of communication and willingness to communicate between farmers and municipal and provincial officials, and with stakeholders with different interests (e.g., those interested in agriculture versus those interested in conservation or catchment management). Mulkerrins (2015:84) sums the situation up as follows: "multi-stakeholder collaboration, communication and interaction is limited and intermittent, and fraught with resentment due to not only the water issue, but to other issues such as Apartheid-related cultural aspects, property, land and municipal taxes..." Farmers are suspicious of efforts to bring them together to collaborate around land and water resources, and it seems that it is currently in the farmers' interests to remain fragmented rather than work as a collective, to avoid government intervention and to maintain what control they have over their land and water resources (de Jong 2012, Mulkerrins 2015).

\section{FINDINGS}

The research findings paint a textured picture of collaboration and collaborative stewardship among the diverse stakeholders of the Langkloof. Although there is evidence of collaboration happening at various levels in the landscape, collaboration is not always easy, and a multitude of factors, both enablers and barriers, influence collaborative stewardship processes and outcomes. The findings are further illustrated through the presentation of three vignettes that give insights into collaboration and collaborative stewardship in different parts of the landscape.

\section{Existing collaborative initiatives}

In contrast to a prevalent perception among stakeholders that there is a general lack of collaboration among farmers and other stakeholders, we identified a wide variety of collaborative initiatives (Table 2, and see Table 3 for more specific vignettes). Farmers collaborate with one another on issues directly related to their farming businesses. They collaborate with other 
Table 3. Vignettes illustrating the factors influencing collaboration in the Langkloof region (see photos in Fig. 2).

\begin{tabular}{|c|c|}
\hline $\begin{array}{l}\text { Name and number of } \\
\text { vignette }\end{array}$ & Vignette details \\
\hline $\begin{array}{l}\text { Vignette } 1(\mathrm{~V} 1) \text { : } \\
\text { Exclusive collaboration } \\
\text { in the Langkloof } \\
\text { Farmers' Association }\end{array}$ & $\begin{array}{l}\text { The Langkloof Farmers Association (LFA) is one of the most important and functional } \\
\text { collaborative initiatives in the Langkloof (Table 2). It is an influential organization in the } \\
\text { Langkloof farming community. Most commercial fruit farmers in the greater Langkloof are } \\
\text { members of the association. Most emerging mixed race farmers do not participate in the LFA, } \\
\text { although they have been invited. } \\
\text { Some of the emerging farmers said that they used to attend the meetings, but they felt } \\
\text { marginalized and their voices were not heard, as this quote illustrates: "I was part of the } \\
\text { Farmers' Association here. In the end, I didn't go anymore... [I] systematically took myself } \\
\text { away from that ... I could see that in this new dispensation there hasn't been a paradigm shift: } \\
\text { they are still speaking the same language, they are still speaking in the same direction." } \\
\text { Possibly in response to this exclusion, the emerging farmers have formed their own } \\
\text { collaborative group, the Koukamma Emerging Farmers Task Team. } \\
\text { In contrast to these experiences of exclusion at the institutional level (in the LFA), many of the } \\
\text { emerging farmers I spoke to had good working relationships with their white farmer neighbors. } \\
\text { For example: "That neighbour of mine sent us managers to help us, that man came every day } \\
\text { to help us. He taught us how to prune, how to take out old trees, how to irrigate, I take my hat } \\
\text { off to that man." } \\
\text { A similar case of farmer-to-farmer linkages across socioeconomic and racial divides in the } \\
\text { Langkloof was described by Hart and Burgess (2006), emphasizing the importance of informal } \\
\text { farmer networks, and individual interpersonal relationships for knowledge exchange and } \\
\text { innovation (see Fig } 2 \text { B) }\end{array}$ \\
\hline
\end{tabular}

Vignette 2 (V2): Historical collaboration for stewardship in soil conservation committees

Vignette 3 (V3): Effective place-based collaborative stewardship in the Zuuranys Conservancy
Many respondents mentioned the "old" soil conservation committees, which were implemented by the previous government (prior to democracy in 1994) through the Conservation of Agricultural Resources Act (No. 43 of 1983). For example:

"... pre-1994 we had a soil conservation policy... we checked that we had fire season, you may only burn [from the] 15 th January to 15 th March and so on. We had oversight as the committee to police it. The soil conservation committees were dropped, now people who don't worry much burn every year, we as a farmers' association still say: this is our policy... but I don't have any means to compel someone to do it, because I am no longer a member of the soil conservation committee, I am just a farmer... we have policies but we don't have policies that have teeth and that can bite."

These committees no longer exist (because of lack of institutional support), yet the guidelines for sustainable land management that they promoted are still law and are followed by some farmers. Many respondents lamented the fact that these committees no longer exist, particularly because they operated as a means of keeping farmers accountable to one another for implementing stewardship practices and for adhering to the law. They also facilitated information sharing. One of the success factors of this initiative appears to have been that it was localized within agricultural subcommunities, because soil conservation committees were usually operational at the local level (below the landscape level). Another related enabler was the fact that members tended to have long-term relationships and high levels of trust in one another. Provision was made for soil conservation committees in legislation, and the committees were supported by government officials creating a formalized and recognized institutional structure "with teeth". The leaders of the committees were usually the existing leaders in the farming community who already had the respect of fellow farmers, highlighting the importance of leadership as an individual enabler (see Fig. 2C).

The Zuuranys Conservancy is a voluntary group of farmers in the agricultural subcommunity called the Suurveld (Fig. 1). This is a small, tight-knit community of mostly sheep farmers. They formed a conservancy (a formal collaborative stewardship initiative recognzsed in legislation) primarily to manage and regulate hunting of game. However, this also enables them to work together to collectively manage invasive alien plants, fire, and soil conservation. The farmers in the Suurveld are proud of their conservancy. Sense of place and identity are important enablers. It also enables them to engage with government officials and other stakeholders on conservation issues and get technical support. It is one of the few examples of functional, collaborative stewardship initiatives in the greater Langkloof.

Leadership and the presence of a champion was a key feature of this successful collaborative endeavor: "....and you've got to have good leadership, and be positive, and motivate people and give good feedback to the people which is relative to the area.... [he's] got a slot there [at meetings], and says alright, we've done this, done hunting, got Hackeas (invasive alien trees) down, and the water started running again... and then the farmers see they can do it for themselves... and so it takes time, but you must have positive feedback to the whole group, you can motivate the whole group and use things to motivate people to see the big picture" (talking about the founding chairman of the conservancy). Long-term relationships were another key feature of this successful collaboration. One official from the Department of Environmental Affairs has been particularly instrumental in supporting this conservancy (we call him Mr. X), playing the role of a champion in enabling this collaboration. "We work together with Nature Conservation with Mr. X on the leopards and so on, we have a friendly relationship, not a department-to-farmer relationship. We try to do things right" (see Fig. 2D).
Insights on factors influencing collaboration, i.e., enablers and barriers

This vignette illustrates the interplay between institutional, social-relational, and politicalhistorical factors. The lesson is that there are deep racial divisions among farmers in the Langkloof, and this is a significant barrier to landscape-level collaborative stewardship. This further entrenches historic social injustices in the region, making it difficult for the benefits of agriculture and natural resources to be shared more equitably. However, the positive interpersonal working relationships between neighboring farmers

(across racial divides) inspire hope. They seem to indicate that it might be at the interpersonal level that racial boundaries can first be overcome. Moreover, formalized institutional processes, which do not pay attention to social-relational and politicalhistorical factors, are unlikely to address deep-seated divides, to achieve equitable landscape-level stewardship.

This vignette illustrates the importance of and social-relational factors and how they interact with institutional factors. The soil conservation committees were a formalized institutional structure for collaborative stewardship supported by the previous government regime. The lesson from this vignette is that when legislated institutionalized collaboration for stewardship between farmers is coupled with local leadership and alignment with other existing activities and direct benefits to farmers, then these can succeed. In the absence of institutional support and monitoring of compliance (a feature of eroding natural resource governance across South Africa), these committees no longer function.

This vignette illustrates how multiple, interacting, mutually reinforcing enablers are needed for collaboration for stewardship to succeed, across the individual, socialrelational, and institutional domains. In this case, the two most prominent enablers of collaboration are strong leadership, and long-term relationships and trust, both within the Suurveld community and with supportive stakeholders (e.g., conservation officials). Formalized, institutional collaborative initiatives are an enabler, although the success of the formal initiative rests on the individual (leaders/champions) and social-relational enablers. 
stakeholders through various fora. There are also numerous collaborative stewardship initiatives that take the form of formal, bureaucratic, and informal, socially embedded collaboration.

These existing collaborative initiatives reveal important insights about the nature of collaboration in the region. They illustrate that there is collaborative capacity in the landscape, and much can be learnt from these existing initiatives about how to foster collaborative stewardship. First, collaboration is needs based and occurs most often between people with a direct shared interest based on their livelihoods or business needs. Second, the Langkloof is a socially heterogeneous place, and collaboration most often takes place between similar people, i.e., people of the same race group, people living in the same agricultural subcommunity or engaged in the same kind of land use, or people with a shared interest in the same landscape function, e.g., conservation, agriculture, tourism, etc. (Fig. 1).

When collaboration, and indeed collaborative stewardship, does occur at higher levels above these groupings, it is often dependent on strong leadership from individual champions or leaders and on the development of new and sometimes difficult interpersonal relationships of trust across racial and other identity or interest boundaries (Table 3). The following quote illustrates the importance of trust for people to collaborate with stakeholders from different interest groups: "I believe that every farmer wants to work together, but with something (a process) that he can trust, or that's reasonable, and not enforced."

\section{Factors influencing collaboration and collaborative stewardship}

We identified five types of enablers and barriers as factors that affect collaboration: contextual, institutional (structural), socialrelational, individual, and political-historical (Table 4). Within these types of factors affecting collaboration, a wide range of different, more specific, factors emerged from the interviews. We identified more factors acting as barriers (190 factors) than as enablers (111 factors) of collaboration, indicating that stakeholders do experience difficulties in collaborating or facilitating collaboration. Although we used the frequency of mention (i.e., the number of interviews in which a factor was mentioned by respondents) as an indication of its significance (Table 4), we also grounded our analysis of the findings in the context of the landscape, using vignettes to further illustrate the most significant factors influencing collaboration (Table 3, see also Fig. 4).

Contextual enablers, e.g., "localized collaboration within agricultural subcommunities" and "shared farming interests across the region" were the most mentioned type of enabler (Table 4), confirming our findings, which reported that the nature of people's interests and their location in the landscape plays a strong role in whom they collaborate with (Table 4). Based on this finding, collaboration in the Langkloof can be described as a patchwork across the landscape. Social-relational enablers, e.g., "social and recreational activities" and "social networks with shared interests" also emerged as important factors with a positive influence on collaboration, and although not mentioned that often in interviews "'long-term relationships and trust between different stakeholders" plays a key role, as all three of the vignettes illustrate (Table 3 ). This supports the premise that collaboration, in general, can enable collaborative stewardship, more specifically.
Fig. 4. Conceptual model illustrating strength of influence of different factors (enablers and barriers) on collaboration. Individual and social-relational factors appear to have the strongest influence. Note: Examples of enablers and barriers in small font taken from Langkloof case data.

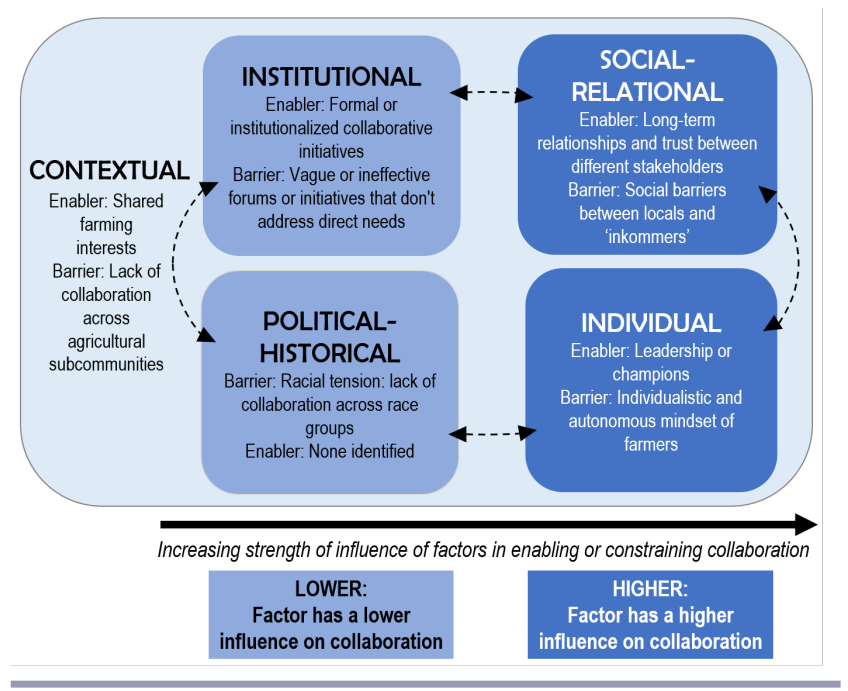

The most mentioned barriers of collaboration were of the socialrelational type, e.g., "social barriers between locals and "inkommers" and "competition and conflict between farmers" (Table 4). Inkommers are new residents or farmers who have moved into the landscape. Related to this are some of the factors listed under political and historical barriers such as "racial tension and lack of collaboration across race groups." Although institutional enablers such as "formal or institutionalized collaborative initiatives" can play a role in bringing people together across contextual and social-relational barriers (Table 3 , vignette 2), the deep-seated racial tensions and mistrust of inkommers held by "old Langkloofers" can make this difficult (Table 3, vignette 1).

Individual factors, operating at the level of individual persons (i.e., human agency) act as enablers (e.g., leadership or champions) and as barriers (e.g. individualistic and autonomous mindset of farmers, the second most mentioned factor across all interviews; Table 4) and interact with other factors to influence collaborative processes (Table 3, vignettes 2 and 3 ).

Taken together, the vignettes illustrate how the different factors interact with one another to influence collaboration (Table 3). For example, although the institutional structure of the Langkloof Farmers' Association is an institutional enabler for white farmers to collaborate, the lack of interpersonal relationships across race groups is a barrier for effective collaboration across a wider diversity of stakeholders within this structure (vignette 1 ). In vignette 2 , a formalized institutional platform functioned well historically, but only with effective support from government officials, an institutional enabler. Without effective leadership and input from an enthusiastic government official, both individual enablers, the Zuuranys Conservancy would not function well as a formal institutional platform (vignette 3 ). 
Table 4. Factors, i.e., enablers and barriers, influencing collaboration in the Langkloof region.

\begin{tabular}{|c|c|c|c|}
\hline $\begin{array}{l}\text { Enablers and barriers of } \\
\text { collaboration }\end{array}$ & Description and examples & $\begin{array}{l}\text { Number of } \\
\text { mentions }\end{array}$ & $\begin{array}{l}\text { Relevant } \\
\text { vignettes } \\
\text { (Table 3) }\end{array}$ \\
\hline \multicolumn{4}{|c|}{ 1. Contextual enablers and barriers (factors that relate to the unique characteristics of the Langkloof context): } \\
\hline Enablers: & & Total: 39 & \\
\hline Localized collaboration within & Each subcommunity has its own culture and shared identity which enables collaboration (e.g., in the & 13 & $\mathrm{~V} 2, \mathrm{~V} 3$ \\
\hline agricultural subcommunities. & Suurveld, most people farm with sheep and they collaborate around road maintenance, see Fig. 2). & & \\
\hline $\begin{array}{l}\text { Shared farming interests } \\
\text { across the region. }\end{array}$ & $\begin{array}{l}\text { Across the Langkloof region people who farm the same things collaborate (e.g., apple farmers share } \\
\text { harvesting equipment). }\end{array}$ & 12 & $\mathrm{~V} 1, \mathrm{~V} 3$ \\
\hline $\begin{array}{l}\text { Shared risks like natural } \\
\text { disasters. }\end{array}$ & $\begin{array}{l}\text { People collaborate to minimize the shared risks they face due to fire, floods, drought, etc. (e.g., farmers } \\
\text { share the cost of fire-fighting equipment). }\end{array}$ & 9 & \\
\hline Consolidation of farms. & $\begin{array}{l}\text { Large companies have moved in and now own many small farms. These farm managers collaborate more } \\
\text { with one another than the previous owners did; there are fewer farmers so there is less conflict (e.g., they } \\
\text { are more likely to share knowledge on new technologies with one another). }\end{array}$ & 5 & \\
\hline Barriers: & & Total: 58 & \\
\hline $\begin{array}{l}\text { Lack of collaboration across } \\
\text { agricultural subcommunities. }\end{array}$ & $\begin{array}{l}\text { The subcommunities tend to be insular and people are suspicious of outsiders and are less likely to } \\
\text { collaborate with them (e.g., sheep farmers in the Suurveld do not trust the apple farmers in the Onder- } \\
\text { Langkloof, see Fig. 2). }\end{array}$ & 19 & \\
\hline Different farming interests. & $\begin{array}{l}\text { Farmers who farm different things are less likely to collaborate with one another (see example of sheep } \\
\text { and apple farmers above). }\end{array}$ & 16 & V1 \\
\hline $\begin{array}{l}\text { Conflict between neighbors } \\
\text { with different land-use } \\
\text { objectives. }\end{array}$ & $\begin{array}{l}\text { Neighboring farmers who use the land for different things often find it difficult to collaborate because } \\
\text { they have different priorities (e.g., a wildlife ranching farm will have different fire-management regimes to } \\
\text { a sheep farm). }\end{array}$ & 13 & \\
\hline $\begin{array}{l}\text { Large spatial scale makes } \\
\text { collaboration difficult. }\end{array}$ & $\begin{array}{l}\text { Collaboration often requires face-to-face meetings. This becomes difficult when it takes people too long } \\
\text { to travel to meetings over long distances, especially when road conditions are poor (e.g., farmers in the } \\
\text { Kouga are less likely to participate in the Langkloof Farmers' Association because of the long travel } \\
\text { distances and times). }\end{array}$ & 10 & \\
\hline \multicolumn{4}{|c|}{ 2. Social-relational enablers and barriers (factors that relate to interpersonal ties between people: between individuals and in the wider social network, i.e., social capital). } \\
\hline Enablers: & & Total: 30 & \\
\hline $\begin{array}{l}\text { Social and recreational } \\
\text { activities. }\end{array}$ & $\begin{array}{l}\text { Social activities like sport and leisure clubs and church activities are considered an important enabler of } \\
\text { collaboration among stakeholders in the Langkloof because they help to build interpersonal } \\
\text { relationships (e.g., farmers who are a part of the local rugby team are more likely to collaborate with } \\
\text { others who are as well). }\end{array}$ & 10 & $\mathrm{~V} 3$ \\
\hline $\begin{array}{l}\text { Social networks with shared } \\
\text { interests. }\end{array}$ & $\begin{array}{l}\text { Loosely organized social networks around shared interests like conservation, cycling, handicrafts, baking, } \\
\text { and childcare build a sense of community and make it more likely for people to collaborate (e.g., parents } \\
\text { who share childcare responsibilities are more likely to collaborate in other ways too). }\end{array}$ & 8 & $\mathrm{~V} 3$ \\
\hline Bridging agents or brokers. & $\begin{array}{l}\text { The presence of individuals who can act as bridging or brokering agents between different } \\
\text { subcommunities or subgroups enhances the likelihood of collaboration beyond these smaller groups (e.g., } \\
\text { a farmer who farms both sheep and apples can bridge between these two types of farmers). }\end{array}$ & 6 & $\mathrm{~V} 3$ \\
\hline $\begin{array}{l}{ }^{*} \text { Long-term relationships and } \\
\text { trust between different } \\
\text { stakeholders. }\end{array}$ & $\begin{array}{l}\text { When there is a long-standing interpersonal relationship between stakeholders, this enhances the quality } \\
\text { of collaboration: they can build on this to extend the collaborative network (e.g., a leading farmer has a } \\
\text { long-standing relationship with a conservation official, subsequently the whole farmers' association now } \\
\text { collaborates more with the conservation authorities). }\end{array}$ & 6 & $\mathrm{~V} 2, \mathrm{~V} 3$ \\
\hline Barriers: & & Total: 64 & \\
\hline $\begin{array}{l}\text { Social barriers between locals } \\
\text { and inkommers. }\end{array}$ & $\begin{array}{l}\text { Local residents of the Langkloof who have been there for many generations are suspicious of outsiders } \\
\text { or newcomers to the area, making collaboration between them difficult (e.g., an elderly farmer expressed } \\
\text { his concern about all the new people in his valley and is frustrated that they don't participate in the } \\
\text { shared fire-management activities). }\end{array}$ & 30 & \\
\hline $\begin{array}{l}\text { Competition and conflict } \\
\text { between farmers. }\end{array}$ & $\begin{array}{l}\text { There is a strong sense of competition among farmers, which can lead to conflict (e.g., farmers compete } \\
\text { to produce the best produce, sometimes at the expense of sharing resources and knowledge). }\end{array}$ & 16 & V1 \\
\hline $\begin{array}{l}\text { Lack of long-term } \\
\text { relationships and trust } \\
\text { between different stakeholders. }\end{array}$ & $\begin{array}{l}\text { There are many small in-groups in the Langkloof (e.g., subcommunities, interest groups, etc.) and } \\
\text { mistrust for people who are different in any number of ways. This results in insularity and a lack of trust } \\
\text { in people who are different. }\end{array}$ & 9 & V1 \\
\hline $\begin{array}{l}\text { Apathy and lack of interest } \\
\text { and participation in } \\
\text { collaborative processes. }\end{array}$ & $\begin{array}{l}\text { Many people are disinterested in formal collaborative processes and feel that there is no benefit from } \\
\text { participating (e.g., farmers feel that there is no benefit in them collaborating around water management } \\
\text { beyond their local water boards). }\end{array}$ & 6 & \\
\hline $\begin{array}{l}\text { Lack of collaboration between } \\
\text { emerging farmers and } \\
\text { commercial farmers. }\end{array}$ & $\begin{array}{l}\text { New emerging (black and mixed race) farmers who have gained access to land are often excluded from } \\
\text { long-standing collaborative processes and can have difficult working relationships with their white } \\
\text { commercial farmer neighbors (e.g., emerging farmers find it difficult to get advice knowledge with their } \\
\text { commercial farmer neighbors). }\end{array}$ & 3 & V1 \\
\hline \multicolumn{4}{|c|}{ 3. Institutional enablers and barriers (factors that relate to formal institutional platforms, arrangements and organizations). } \\
\hline Enablers: & & Total: 24 & \\
\hline $\begin{array}{l}{ }^{*} \text { Formal or institutionalized } \\
\text { collaborative initiatives. }\end{array}$ & $\begin{array}{l}\text { Formal platforms for collaboration can enhance collaboration because they build shared accountability } \\
\text { (e.g., the fire protection association to which members are mandated to pay membership fees functions } \\
\text { well). }\end{array}$ & 11 & $\mathrm{~V} 2, \mathrm{~V} 3$ \\
\hline $\begin{array}{l}\text { Schools and churches act as } \\
\text { hubs of social networks. }\end{array}$ & $\begin{array}{l}\text { Formal community institutions bring people together and help to build interpersonal relationships across } \\
\text { other divides (e.g., even though and apple farmer and a sheep farmer don't always get along, if they go to } \\
\text { the same church they are more likely to collaborate). }\end{array}$ & 9 & V3 \\
\hline
\end{tabular}




\begin{tabular}{|c|c|c|c|}
\hline $\begin{array}{l}\text { Aligning collaborative } \\
\text { initiatives to reduce } \\
\text { administrative load. }\end{array}$ & $\begin{array}{l}\text { When formal initiatives serve similar functions and have a similar membership, aligning them can reduce } \\
\text { the number of meetings and administrative tasks (e.g., one farmer group has combined leadership and } \\
\text { meetings for the fire association and the farmers' association). }\end{array}$ & 4 & $\mathrm{~V} 2, \mathrm{~V} 3$ \\
\hline \multicolumn{2}{|r|}{ 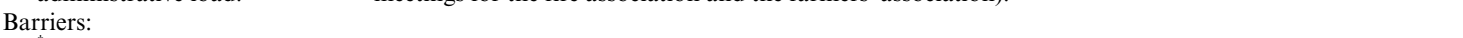 } & \multicolumn{2}{|l|}{ Total: 13} \\
\hline $\begin{array}{l}\text { "Vague or ineffective forums or } \\
\text { initiatives that don't address } \\
\text { direct needs. }\end{array}$ & $\begin{array}{l}\text { When formal platforms for collaboration are set up but do not speak to stakeholders needs or interest, } \\
\text { they can result in apathy and a lack of interest in collaboration (e.g., a conservation platform was set up } \\
\text { to include farmers in conservation but the benefits to farmers were unclear and they felt frustrated). }\end{array}$ & 10 & V1 \\
\hline $\begin{array}{l}\text { Lack of government support } \\
\text { and financial resources. }\end{array}$ & $\begin{array}{l}\text { When there is a mandate for government to provide resources to support collaborative processes and this } \\
\text { is not happening, it frustrates stakeholders (e.g., formal catchment management forums should be } \\
\text { financed by government and driven by government officials, but this is not taking place because of poor } \\
\text { governance within the water sector). }\end{array}$ & 3 & $\mathrm{~V} 2$ \\
\hline \multicolumn{4}{|c|}{ 4. Individual enablers and barriers (factors that relate to the characteristics of individual people and how these influence collaborative processes). } \\
\hline \multicolumn{2}{|c|}{ Enablers: } & \multicolumn{2}{|l|}{ Total: 18} \\
\hline "Leadership or champions. & $\begin{array}{l}\text { Individuals who take a lead and champion an initiative can be a significant enabler because they inspire } \\
\text { others and help to create momentum (e.g., a farmer who leads a small conservancy committee has } \\
\text { inspired many others to join and implement stewardship actions through his leadership and enthusiasm). }\end{array}$ & 14 & $\mathrm{~V} 2, \mathrm{~V} 3$ \\
\hline $\begin{array}{l}\text { Good communication and } \\
\text { people skills (relational skills). }\end{array}$ & $\begin{array}{l}\text { Individuals who have good communication and people skills can have a positive influence on } \\
\text { collaborative processes (e.g., stakeholders mentioned that a certain conservation official is a good listener } \\
\text { and cares about their interests, and they are more likely to participate in collaborative initiatives that he } \\
\text { organizes). }\end{array}$ & 4 & \\
\hline \multicolumn{2}{|r|}{ Tim } & \multicolumn{2}{|l|}{ Total: 28} \\
\hline $\begin{array}{l}{ }^{*} \text { Individualistic and } \\
\text { autonomous mindset of } \\
\text { farmers. }\end{array}$ & $\begin{array}{l}\text { Many respondents noted that farmers in the Langkloof are very individualistic and focused on their own } \\
\text { needs and interests. This relates to a self-sufficiency mindset too (e.g., a farmer feels that he needs to } \\
\text { secure the success of his own farming business first, and then he can collaborate in shared water } \\
\text { arrangements). }\end{array}$ & 25 & V1 \\
\hline $\begin{array}{l}\text { Poor communication and } \\
\text { people skills (relational skills). }\end{array}$ & $\begin{array}{l}\text { If collaborative initiatives are run by people who do not have good communication and people skills, they } \\
\text { are less likely to succeed because stakeholders don't feel cared for and listened to (e.g., a stakeholder } \\
\text { mentioned that a researcher tried to involved him in a collaborative process but that the researcher did } \\
\text { not treat the stakeholders well and did not communicate well, so they didn't want to participate). }\end{array}$ & 3 & \\
\hline \multicolumn{4}{|c|}{$\begin{array}{l}\text { 5. Political-historical enablers and barriers (Factors that relate to the political context and the influence of historical processes on collaboration in the Langkloof } \\
\text { colonial and Apartheid history, and the current political situation in the country, have a strong influence on collaboration; see Table 1). }\end{array}$} \\
\hline Enablers: & & \multicolumn{2}{|l|}{ Total: 0} \\
\hline None mentioned. & & 0 & \\
\hline \multicolumn{2}{|l|}{ Barriers: } & \multicolumn{2}{|l|}{ Total: 27} \\
\hline $\begin{array}{l}\text { Racial tension and lack of } \\
\text { collaboration across race } \\
\text { groups. }\end{array}$ & $\begin{array}{l}\text { A lack of interpersonal relationships and trust among people of different race groups makes } \\
\text { collaboration difficult and leads to exclusion of black and mixed race stakeholders from collaborative } \\
\text { platforms. People usually collaborate within race groups rather than across them (e.g., few black or mixed } \\
\text { race emerging farmers are involved in the Langkloof Farmers Association because they do not feel } \\
\text { welcome in a space dominated by white commercial farmers). }\end{array}$ & 20 & V1 \\
\hline $\begin{array}{l}\text { Perceived political interference } \\
\text { and conflicts around land } \\
\text { rights and land-claim } \\
\text { processes. }\end{array}$ & $\begin{array}{l}\text { Farmers feel that there is political interference in the way in which land use is governed (e.g., this mostly } \\
\text { related to white farmers' unease with regard to land and water redistribution processes and leads to } \\
\text { mistrust between farmers and government officials). }\end{array}$ & 5 & \\
\hline $\begin{array}{l}\text { Unequal power dynamics, } \\
\text { particularly along racial lines. }\end{array}$ & $\begin{array}{l}\text { In collaborative processes, decision-making power is often unequally distributed (e.g., white farmers who } \\
\text { are privileged and have greater access to land, water, education, and other resources have a greater } \\
\text { influence in decision-making processes). }\end{array}$ & 2 & V1 \\
\hline
\end{tabular}

The barriers to collaboration identified (Tables 3, 4) go some way to explaining why Living Lands have experienced challenges in facilitating collaborative stewardship among farmers, and between farmers and other stakeholders at the landscape level (Box 1). There are multiple social-relational barriers at play including: barriers between locals and inkommers (e.g., new residents and farmers, government officials, Living Lands, and other NGOs are usually considered inkommers and are treated with suspicion); lack of long-term relationships and trust between different stakeholders from different interest groups (e.g., conservation, catchment management, and agriculture); difficulties in working with the government; and tensions between different race groups.

\section{DISCUSSION}

The Langkloof story sheds light on some of the challenges that are encountered worldwide when efforts are made to facilitate collaborative, landscape-level stewardship initiatives. The case particularly offers a warning to practitioners and scholars alike who seek to support such initiatives in contexts in which deep historical divisions and inequality continue to permeate everyday relationships. However, while providing a cautionary tale, the case also helps to identify ways forward and options for moving toward collaborative stewardship in contested multifunctional landscapes. In particular, the case study suggests that individual and socialrelational factors play a major role in affecting collaboration. Small, bottom-up patches of collaboration based on interpersonal relationships and social networks can form the basis for more formal collaborative stewardship platforms at landscape level (Cockburn et al. 2019b). A relational, patchwork approach to collaboration might therefore be better suited to contested, heterogeneous landscapes. We unpack each of these insights in turn, propose principles for implementing a relational, pluralistic approach, and then consider implications for future research on collaboration.

\section{Role of individual and social-relational factors for collaborative stewardship}

The findings demonstrate the strong influence of the socialecological and historical context on collaborative outcomes in the 
Langkloof (Tables 1-4) and bring to the fore the interplay between factors influencing collaboration (Fig. 4). Similarly, Patterson et al. (2017) found a range of factors interacting to enable or constrain collaborative stewardship in contested contexts. We suggest, however, that some factors have a stronger influence on collaboration than others (Fig. 4). Social-relational and individual factors have the strongest influence, followed by institutional and political-historical, which are all embedded in and interact with contextual factors. Moreover, although some factors can be influenced to some degree by practitioners facilitating collaboration (social-relational, individual, institutional), others operate somewhat beyond the control of practitioners (contextual, political-historical; Ayala-Orozco et al. 2018).

In the Langkloof, individual and social-relational factors operate as underlying mechanisms, which strongly influence possibilities for effective collaboration (Fig. 4). Not only were social-relational barriers the most frequently mentioned type of barriers to collaboration, but the vignettes illustrate that individual and social-relational factors play a strong role in shaping the outcome of collaborative initiatives (Table 4). These factors are particularly crucial in contexts of poor or eroding governance (Cleaver 2012). In such contexts, the ability of individuals and small, motivated groups to work together outside of the bounds of institutional support becomes even more important (Cleaver 2012). This highlights the importance of widely recognized relational enablers of collaboration such as trust (Hahn et al. 2006, Patterson 2017), social networks and social capital (Pretty and Smith 2004, Church and Prokopy 2017), and leadership (Hahn et al. 2006, Church and Prokopy 2017).

This case study suggests that practitioners, especially those working in NGO/NPOs with more flexibility, should pursue relationship-building, bridging, and brokering opportunities in the landscape (Hahn et al. 2006) to stitch together the collaborative patchwork. Existing literature on collaboration often pays attention to structural factors, such as institutional design and cross-scale governance mechanisms that can support collaborative efforts (Ostrom 2005, Armitage et al. 2007a, Plummer et al. 2012). However, experiences in the Langkloof suggest that individual and social-relational enablers potentially have the strongest influence on collaborative outcomes because they have the potential to overcome barriers in the other domains (Fig. 4, Table 4). This recommendation echoes recent calls for a relational understanding of stewardship (Peçanha Enqvist et al. 2018) and for paying attention to the interdependence of social actors in collaborative processes (Zachrisson and Beland Lindahl 2013).

\section{Contested landscapes call for patchworks of collaboration}

Collaboration in the Langkloof is needs based and directly related to the business of farming or shared interests of stakeholders, taking the form of a patchwork across the landscape. We therefore propose a patchwork approach to collaboration premised on the notion of pluralism.

One of the most important contextual enablers of collaborative stewardship is a common concern entry point (Sayer et al. 2013). If a landscape-level initiative does not have a sufficiently pressing issue that is shared by the multiple, diverse stakeholders across the landscape, then blanket collaboration through a single multistakeholder governance platform is not likely to be suitable.
This large-scale blanket approach is sometimes implied in the literature on landscape approaches (Everard 2011, Plieninger et al. 2015) and in integrated catchment management (Lubell 2004), but has also been critiqued (Wollenberg et al. 2005, Ferreyra et al. 2008).

Despite the importance of a landscape-level approach to stewardship (Cockburn et al. 2018), and wide recognition for consensus-based collaboration (Wondolleck and Yaffee 2000, Ansell and Gash 2007, Margerum and Robinson 2016b), this may not always be possible, particularly in landscapes characterized by contestation (Wollenberg et al. 2005, Zachrisson and Beland Lindahl 2013). Plural, dispersed, and diverse patchworks of collaboration, based on localized shared needs and interests, may be more realistic than a blanket approach to collaboration across the whole landscape. Diversity and differences between people should be not viewed as problems to be overcome, but as realistic starting points and potential sources of creativity and resilience in complex landscapes (Wollenberg et al. 2005).

Although we recommend an approach that fosters plural, dispersed, diverse collaboration across the landscape, this must not be done in a way that perpetuates the status quo in the landscape. Links across these groups, or a slow but steady stitching together of the patchwork of collaboration, are needed to achieve the visions of sustainable and just pathways for the entire landscape (Leach et al. 2013). This requires excellent bridging and social facilitation skills (Cockburn et al. 2019b), and an approach that pays attention to social-relational and individual factors that influence collaboration. The patchwork approach can be implemented, and the patchwork stitched together, through small local stewardship actions to bring people together in novel constellations. Collaboration can in fact "emerge" from such small-scale collective actions (Church and Prokopy 2017, Patterson 2017), even if the social preconditions or enablers of collaboration do not exist in the first place (Babin et al. 2016). Practitioners facilitating collaboration in multistakeholder, multiple-objective, contested landscapes should simultaneously support bottom-up collective action while developing mechanisms to support collaborative stewardship at the higher landscape level (Minang et al. 2014b).

\section{Principles for a relational, pluralistic approach to collaboration} A relational, pluralistic approach to fostering collaborative stewardship should be guided by the following key principles (drawn from the findings of this study and others as cited in brackets):

1. Support the development of individual and collective agency and new interpersonal relationships among disparate actors through small collective actions toward landscape stewardship (Ansell and Gash 2007, Patterson 2017);

2. Recognize pluralism as a fundamental feature of socialecological systems and work with diversity rather than trying to "flatten" it (Wollenberg et al. 2005);

3. Build collaboration from the bottom up by stitching together or brokering between patches of collaboration already existing in landscapes; informal social-relational networks can lay the groundwork and develop the social capital and trust that are needed to make higher level, more formal, platforms work well (Cockburn et al. 2019b); 
4. Support NGOs and other local practitioners to reflexively learn-by-doing in their efforts to foster collaborative stewardship, rather than recommending the naïve implementation of externally developed design principles or guidelines for collaboration (Ferreyra et al. 2008);

5. Appreciate that collaboration is situated in a context shaped by history, culture, politics, and existing power dynamics (Fabinyi et al. 2014, Saunders 2014);

6. Understand this context and build relationships with and among stakeholders; this takes time and requires relational competencies and leadership skills (Cockburn et al. 2019b).

\section{Implications for research on collaborative stewardship}

Relational, pluralistic approaches to fostering collaborative stewardship in multifunctional landscapes are not well-researched (but see Wollenberg et al. 2005 and Ferreyra et al. 2008). Our case illustrates that in contested, multifunctional landscapes the welltrodden path of implementing design principles for collaboration and putting in place formal, bureaucratic collaborative governance institutions appear not to work easily.

Existing thinking on collaboration for natural resource management highlights both structural and social-relational factors, which influence collaborative processes. However, structural aspects and behavioral-economic and institutional approaches (e.g., Armitage et al. 2007a and Ostrom 2005) still dominate much of the discourse (Sandström 2009, Saunders 2014). To support collaborative processes according to the above principles, more work needs to be done to understand socialrelational factors. Although there is a growing body of research on social networks, which takes a relational perspective (Alexander and Armitage 2015, Bodin 2017), the role of human agency, the influence of social diversity, and processes of intersubjectivity among actors involved in collaboration are still not well understood (Cleaver 2012, Fabinyi et al. 2014, Cockburn et al. 2018). Considering the importance of individual and socialrelational enablers raised in this case study (Fig. 4), these areas should be prioritized in future research. Addressing this gap will require studies focused on socially embedded forms of collaboration (not only bureaucratic forms) that look into the influence of historical, political, and cultural processes (Cleaver 2002, 2007). Landscape stakeholders need to be understood as actors embedded in multiple network relations with differentiated influence, interests, and responsibilities (Saunders 2014).

Furthermore, research to support a relational, pluralistic approach to collaboration requires a clearer focus on underlying politics and power dynamics that influence collaboration. Such research could draw on more critical social science approaches to collaboration and governance such as critical institutionalism (de Koning 2014, Cleaver and de Koning 2015), the pathways approach (Leach et al. 2007), and political ecology (Fabinyi et al. 2014).

The lessons from the Langkloof case raise some challenging questions: Is collaboration an ideal that we should still be aiming for in landscape stewardship? And if so, might it look different in the contested landscape settings typical of settings of weak governance that are typical of the Global South? It is our opinion that collaboration still holds potential benefits for people and nature in multifunctional landscapes and that it should be pursued. However, a bottom-up patchwork approach to collaboration, which is based on a nuanced, situated understanding of local communities, is needed, rather than a blanket approach in which people are forced together into landscape-level platforms and institutions when they might not be ready.

\section{CONCLUSION}

Although formalized governance processes and institutions play an important role in fostering collaboration, individual and social-relational factors may in fact be the pivotal enablers that create the fabric for collaboration. These in turn are influenced by contextual and political-historical factors and processes. Our engaged research in the Langkloof suggests that a patchwork, rather than a blanket, approach to building collaboration is better suited to complex, contested contexts. This approach, based on pluralism, could start with localized, collective stewardship actions based on diverse stewards' needs and interest, from which collaboration could emerge. Practitioners seeking to foster collaboration should keep an eye out for windows of opportunities to stitch together the collaborative patchwork across the landscape, which will rely on the development of new interpersonal relationships and linkages across stakeholder groups, horizontally and vertically. A commitment to landscapelevel social-ecological sustainability requires explicit recognition of social diversity and inequalities and a commitment to confronting these in a meaningful way. Taking a relational, pluralistic approach to fostering collaborative stewardship is therefore particularly important in contested, socially heterogeneous landscapes, and we have suggested principles to guide such an approach. Future research on collaborative stewardship in such contexts should take a situated approach and focus on social-relational factors that influence collaborative processes.

${ }^{[1]}$ The use of the terms "black," "white," and "colored" to classify groups of people is an unfortunate legacy of the Apartheid regime in South Africa and its colonial history. These terms are still used today, although they are contested (Table 1). They loosely mean the following: black means black African, white means of European origin, and colored means of a mixed ancestry native to Southern Africa. Many individuals and groups self-identify as colored and do not consider this term derogatory. To avoid offence, this paper however uses the term "mixed race" to refer to colored individuals and communities in the Langkloof region.

Responses to this article can be read online at: http://www.ecologyandsociety.org/issues/responses. php/11085

\section{Acknowledgments:}

First and foremost, we thank the people of the Langkloof and stakeholders who support the landscape for participating in this research. We also thank Matthew Septhon, Catherine Andersson, Liezl le Roux, Justin Gird, Julia Glenday, Jocelynn Jacobs, Maura Talbot, Kris Marais, Thelani Grant, Larissa Koch, and Zarra de 
Laat for their contributions to Living Lands' work in in the Langkloof and to this study. Living Lands acknowledges the Table Mountain Fund for supporting their stakeholder mobilization work in the Langkloof. JC acknowledges the following funding sources: the NRF-DST Innovation Doctoral Research Scholarship, the Department of Environmental Affairs: Chief Directorate Natural Resource Management for operational funding through the Thicket programme, and Rhodes University for the Henderson Scholarship (2015-2017) and a Postdoctoral Fellowship (2018-2019). GC acknowledges National Research Foundation support through grants 93446 and 90694. MR acknowledges the South African Research Chairs Initiative of the Department of Science and Technology and the NRF. SS acknowledges Rhodes University for Research funds. The financial assistance of the National Research Foundation (NRF) toward this research is hereby acknowledged.

\section{LITERATURE CITED}

Alexander, S. M., and D. Armitage. 2015. A social relational network perspective for MPA science. Conservation Letters 8 (1):1-13. https://doi.org/10.1111/conl.12090

Ansell, C., and A. Gash. 2007. Collaborative governance in theory and practice. Journal of Public Administration Research and Theory 18:543-571. http://dx.doi.org/10.1093/jopart/mum032

Armitage, D., F. Berkes, and N. Doubleday. 2007a. Adaptive comanagement: collaboration, learning, and multi-level governance. UBC Press, Vancouver, British Columbia, Canada.

Armitage, D., F. Berkes, and N. Doubleday. 2007b. Introduction: moving beyond co-management. Pages 1-15 in D. Armitage, F. Berkes, and N. Doubleday, editors. Adaptive co-management: collaboration, learning, and multi-level governance. UBC Press, Vancouver, British Columbia, Canada.

Ayala-Orozco, B., J. A. Rosell, J. Merçon, I. Bueno, G. AlatorreFrenk, A. Langle-Flores, and A. Lobato. 2018. Challenges and strategies in place-based multi-stakeholder collaboration for sustainability: learning from experiences in the global South. Sustainability 10(9):3217. http://doi.org/10.3390/su10093217

Babin, N., N. D. Mullendore, and L. S. Prokopy. 2016. Using social criteria to select watersheds for non-point source agricultural pollution abatement projects. Land Use Policy 55:327-333. http://doi.org/10.1016/j.landusepol.2015.06.021

Balvanera, P., R. Calderón-Contreras, A. J. Castro, M. R. FelipeLucia, I. R. Geijzendorffer, S. Jacobs, B. Martín-López, U. Arbieu, C. I. Speranza, B. Locatelli, N. P. Harguindeguy, I. R. Mercado, M. J. Spierenburg, A. Vallet, L. Lynes, and L. Gillson. 2017. Interconnected place-based social-ecological research can inform global sustainability. Current Opinion in Environmental Sustainability 29:1-7. http://doi.org/10.1016/j.cosust.2017.09.005

Bazeley, P. 2012. Integrative analysis strategies for mixed data sources. American Behavioral Scientist 56(6):814-828. http://doi. org/10.1177/0002764211426330

Beinart, W. 2000. African history and environmental history. African Affairs 99(395):269-302. https://doi.org/10.1093/afraf/99.395.269

Bennett, N. J., T. S. Whitty, E. Finkbeiner, J. Pittman, H. Bassett, S. Gelcich, and E. H. Allison. 2018. Environmental stewardship: a conceptual review and analytical framework. Environmental Management 61(4):597-614. http://doi.org/10.1007/s00267-017-0993-2
Bieling, C., and T. Plieninger. 2017. The science and practice of landscape stewardship. Cambridge University Press, Cambridge, United Kingdom. https://doi.org/10.1017/9781316499016

Bodin, Ö. 2017. Collaborative environmental governance: achieving collective action in social-ecological systems. Science 357(6352):eaan1114. http://doi.org/10.1126/science.aan1114

Bodin, Ö., and B. I. Crona. 2009. The role of social networks in natural resource governance: what relational patterns make a difference? Global Environmental Change 19(3):366-374. http:// doi.org/10.1016/j.gloenvcha.2009.05.002

Brasser, A., and W. Ferwerda. 2015. Four returns from landscape restoration: a systemic and practical approach to restore degraded landscapes. Commonland Foundation, Amsterdam, The Netherlands. [online] URL: https://www.iucn.org/sites/dev/files/ import/downloads/commonlandpublicationv1lr 269496814.pdf

Chapin, F. S., III, G. P. Kofinas, C. Folke, S. R. Carpenter, P. Olsson, N. Abel, R. Biggs, R. L. Naylor, E. Pinkerton, D. M. Stafford, W. Steffen, B. Walker, and O. R. Young. 2009. Resiliencebased stewardship: strategies for navigating sustainable pathways in a changing world. Pages 319-337 in F. S. Chapin, G. P. Kofinas, and C. Folke, editors. Principles of ecosystem stewardship: resilience-based natural resource management in a changing world. Springer, New York, New York, USA. https://doi. org/10.1007/978-0-387-73033-2_15

Church, S. P., and L. S. Prokopy. 2017. The influence of social criteria in mobilizing watershed conservation efforts: a case study of a successful watershed in the midwestern U.S. Land Use Policy 61:353-367. https://doi.org/10.1016/j.landusepol.2016.11.030

Cleaver, F. 2002. Reinventing institutions: bricolage and the social embeddedness of natural resource management. European Journal of Development Research 14(2):11-30. https://doi. org/10.1080/714000425

Cleaver, F. 2007. Understanding agency in collective action. Journal of Human Development 8(2):223-244. https://doi. org/10.1080/14649880701371067

Cleaver, F. 2012. Development through bricolage: rethinking institutions for natural resource management. Routledge, Oxon, United Kingdom. https://doi.org/10.4324/9781315094915

Cleaver, F. D., and J. de Koning. 2015. Furthering critical institutionalism. International Journal of the Commons 9(1):1-18. http://dx.doi.org/10.18352/ijc.605

Cockburn, J. J. 2018. Stewardship and collaboration in multifunctional landscapes: a transdisciplinary enquiry. Dissertation. Department of Environmental Science, Rhodes University, Grahamstown, South Africa. [online] URL: https://pdfs. semanticscholar.org/f265/370fff75885bb16bdc57fcd574826fa67a02. pdf

Cockburn, J., G. Cundill, C. Shackleton, and M. Rouget. 2018. Towards place-based research to support social-ecological stewardship. Sustainability 10(5):1434. http://doi.org/10.3390/ $\underline{\text { su10051434 }}$

Cockburn, J., G. Cundill, S. Shackleton, and M. Rouget. $2019 a$. The meaning and practice of stewardship in South Africa. South African Journal of Science 115(5/6):5339. https://doi. org/10.17159/sajs.2019/5339 
Cockburn, J., G. Cundill, S. Shackleton, A. Cele, S. F. Cornelius, V. Koopman, J.-P. le Roux, N. McLeod, M. Rouget, S. Schroder, D. van den Broeck, D. R. Wright, and M. Zwinkels. $2019 b$. Relational hubs for collaborative landscape stewardship. Society and Natural Resources. https://doi.org/10.1080/08941920.2019.1658141

Crona, B., H. Ernstson, C. Prell, M. Reed, and K. Hubacek. 2011. Combining social network approaches with social theories to improve understanding of resource governance, Pages 44-71 in $\mathrm{O}$. Bodin, and C. Prell, editors. Social networks and natural resource management: uncovering the social fabric in environmental governance. Cambridge University Press, Cambridge, UK. https://doi.org/10.1017/cbo9780511894985.004

de Jong, T. 2012. Fragmentation as a collective interest: a case study about irrigating farmers, water scarcity, and collective action in the Upper Kromme River Catchment, South Africa. Thesis. Wageningen University, Wageningen, The Netherlands.

de Kock, C. 2015. Farming in the Langkloof: coping with and adapting to environmental shock and social stress. Thesis. University of Stellenbosch, Stellenbosch, South Africa. [online] URL: https://scholar.sun.ac.za/handle/10019.1/97054

de Koning, J. 2014. Unpredictable outcomes in forestrygovernance institutions in practice. Society and Natural Resources 27(4):358-371. http://dx.doi.org/10.1080/08941920.2013.861557

de Laat, Z. 2017. The presumed increase of access due to redistribution of property rights in rural South Africa an analysis of policies and daily practices on land reform farms in the Langkloof. Thesis. Wageningen University, Wageningen, The Netherlands. [online] URL: https://edepot.wur.nl/416518

Draugelyte, E. 2012. Dissonance in social learning: towards maintenance of natural resources in the Kouga Catchment, South Africa. Thesis. Wageningen University, Wageningen, The Netherlands. https://edepot.wur.n1/243094

du Toit, R. 1931. Farming in the Humansdorp and Langkloof areas. Farming in South Africa 6(66):235-238.

Everard, M. 2011. Common ground: the sharing of land and landscapes for sustainability. Zed, London, UK.

Fabinyi, M., L. Evans, and S. J. Foale. 2014. Social-ecological systems, social diversity, and power: insights from anthropology and political ecology. Ecology and Society 19(4):28. http://dx.doi. org/10.5751/ES-07029-190428

Ferreyra, C., R. C. de Loë, and R. D. Kreutzwiser. 2008. Imagined communities, contested watersheds: challenges to integrated water resources management in agricultural areas. Journal of Rural Studies 24(3):304-321. https://doi.org/10.1016/j.

jrurstud.2007.11.001

Fischer, J., M. Meacham, and C. Queiroz. 2017. A plea for multifunctional landscapes. Frontiers in Ecology and the Environment 15(2):59. http://dx.doi.org/10.1002/fee.1464

Floress, K., S. Connolly, K. E. Halvorsen, A. Egan, T. Schuler, A. Hill, P. DeSenze, S. Fenimore, and K. Karriker. 2018. Implementing landscape scale conservation across organizational boundaries: lessons from the central Appalachian Region, United States. Environmental Management 62:845-857. http://doi. org/10.1007/s00267-018-1081-y
Folke, C., R. Biggs, A. V. Norström, B. Reyers, and J. Rockström. 2016. Social-ecological resilience and biosphere-based sustainability science. Ecology and Society 21(3):41. http://doi.org/10.5751/ ES-08748-210341

Frost, P., B. Campbell, G. Medina, and L. Usongo. 2006. Landscape-scale approaches for integrated natural resource management in tropical forest landscapes. Ecology and Society 11 (2):30. https://doi.org/10.5751/ES-01932-110230

Gray, B. 1985. Conditions facilitating interorganizational collaboration. Human Relations 38(10):911-936. http://dx.doi. org/10.1177/001872678503801001

Guelke, L., and R. Shell. 1992. Landscape of conquest: frontier water alienation and Khoikhoi strategies of survival, 1652-1780. Journal of Southern African Studies 18(4):803-824. https://doi. org//10.1080/03057079208708339

Hahn, T., P. Olsson, C. Folke, and K. Johansson. 2006. Trustbuilding, knowledge generation and organizational innovations: the role of a bridging organization for adaptive comanagement of a wetland landscape around Kristianstad, Sweden. Human Ecology 34(4):573-592.

Hamann, M., and V. Tuinder. 2012. Introducing the Eastern Cape: a quick guide to its history, diversity and future challenges. Stockholm Resilience Centre, Stockholm, Sweden. [online] URL: https://www.sapecs.org/wp-content/uploads/2013/11/Eastern-CapeBackground-Report.pdf

Joubert, E., M. E. Joubert, C. Bester, D. de Beer, and J. H. De Lange. 2011. Honeybush (Cyclopia spp.): from local cottage industry to global markets - the catalytic and supporting role of research. South African Journal of Botany 77(4):887-907. http:// doi.org/10.1016/j.sajb.2011.05.014

Kou-Kamma Local Municipality. 2009. Kou-Kamma local municipality situation analysis: local economic development strategy final report. Urban-Econ Development Economists, Port Elizabeth, South Africa.

Kou-Kamma Local Municipality. 2012. Kou-Kamma local municipality: integrated local development plan: 2012-2017. KouKamma Local Municipality, Kareedouw, South Africa. [online] URL: https://www.ecsecc.org/documentrepository/informationcentre/ Koukammal idp 2017.pdf

Lang, D. J., A. Wiek, M. Bergmann, M. Stauffacher, P. Martens, P. Moll, M. Swilling, and C. J. Thomas. 2012. Transdisciplinary research in sustainability science: practice, principles, and challenges. Sustainability Science 7(1):25-43. http://doi. org/10.1007/s11625-011-0149-X

Leach, M., G. Bloom, A. Ely, P. Nightingale, I. Scoones, E. Shah, and A. Smith. 2007. Understanding governance: pathways to sustainability. STEPS working Paper 2. STEPS Centre, Brighton, UK. [online] URL: https://pdfs.semanticscholar. org/580e/4dc1cc9c9d9426ab5de4acab4c233094c32e.pdf

Leach, M., K. Raworth, and J. Rockström. 2013. Between social and planetary boundaries: navigating pathways in the safe and just space for humanity. Pages 84-89 in International Social Science Council and United Nations Educational, Scientific and Cultural Organization, editors. World social science report 2013: 
changing global environments. OECD and UNESCO, Paris, France. https://doi.org/10.1787/9789264203419-10-en

Living Lands. 2017. Eight years on the landscape: the current state of Living Lands. Living Lands, Cape Town, South Africa. [online] URL: https://livinglands.co.za/wp-content/uploads/2017/05/EightYears-on-the-Landscape.x21789.pdf

Lubell, M. 2004. Collaborative watershed management: a view from the grassroots. Policy Studies Journal 32(3):341-361. http:// doi.org/10.1111/j.1541-0072.2004.00069.X

Mander, M., J. Blignaut, M. Van Niekerk, R. Cowling, M. Horan, D. Knoesen, A. Mills, M. Powell, and R. Schulze. 2010. Baviaanskloof-Tsitsikamma payment for ecosystem services: a feasibility study synthesis report. Future Works Sustainability Consulting for SANBI, CAPE, Working for Water, and UNDP, Durban, South Africa. [online] URL: https://www.cbd.int/doc/ meetings/im/wscbteeb-mena-01/other/wscbteeb-mena-01-pes-feasibilityassessment-en.pdf

Margerum, R. D., and C. J. Robinson. 2016a. The challenges of collaboration in environmental governance: barriers and responses. Edward Elgar, Cheltenham, UK.

Margerum, R. D., and C. J. Robinson. 2016b. Introduction: the challenges of collaboration in environmental governance, Pages 1-24 in R. D. Margerum, and C. J. Robinson, editors. The challenges of collaboration in environmental governance: barriers and responses. Edward Elgar, Cheltenham, UK.

Mathevet, R., F. Bousquet, and C. M. Raymond. 2018. The concept of stewardship in sustainability science and conservation biology. Biological Conservation 217:363-370. http://doi. org/10.1016/j.biocon.2017.10.015

Maxwell, J. A. 2012. A realist approach for qualitative research. Sage, Thousand Oaks, California, USA.

McClure, A. 2012. Opportunity and connectivity: selecting land managers for involvement in a conservation corridor linking two protected areas in the Langkloof Valley, South Africa. Thesis. Rhodes University, Grahamstown, South Africa.

Minang, P. A., M. van Noordwijk, O. E. Freeman, L. A. Duguma, C. Mbow, J. de Leeuw, and D. Catacutan. 2014a. Introduction and basic propositions. Pages 3-17 in P. A. Minang, M. van Noordwijk, O. E. Freeman, C. Mbow, J. de Leeuw, and D. Catacutan, editors. Climate-smart landscapes: multifunctionality in practice. World Agroforestry Centre (ICRAF), Nairobi, Kenya. [online] URL: http://www.asb.cgiar.org/climate-smart-landscapes/

Minang, P. A., M. van Noordwijk, O. E. Freeman, C. Mbow, J. de Leeuw, and D. Catacutan. 2014b. Climate-smart landscapes: multifunctionality in practice. World Agroforestry Centre (ICRAF), Nairobi, Kenya. [online] URL: http://www.asb.cgiar. org/climate-smart-landscapes/

Mulkerrins, J. 2015. Scale framing in a landscape restoration process: the case of water in the Langkloof, South Africa. Thesis. Wageningen University, Wageningen, The Netherlands. [online] URL: https://edepot.wur.nl/338435

Ostrom, E. 1990. Governing the commons: the evolution of institutions for collective action. Cambridge University Press, New York, New York, USA.
Ostrom, E. 2005. Understanding institutional diversity. Princeton University Press, Princeton, New Jersey, USA.

Ostrom, E., and M. Cox. 2010. Moving beyond panaceas: a multitiered diagnostic approach for social-ecological analysis. Environmental Conservation 37(4):451-463. http://doi.org/10.1017/ $\underline{\mathrm{S} 0376892910000834}$

Patterson, J. 2017. Purposeful collective action in ambiguous and contested situations: exploring 'enabling capacities' and crosslevel interplay. International Journal of the Commons 11 (1):248-274. http://doi.org/10.18352/ijc.696

Peçanha Enqvist, J., S. West, V. A. Masterson, L. J. Haider, U. Svedin, and M. Tengö. 2018. Stewardship as a boundary object for sustainability research: linking care, knowledge and agency. Landscape and Urban Planning 179:17-37. http://doi.org/10.1016/ j.landurbplan.2018.07.005

Penker, M. 2017. Organising adaptive and collaborative landscape stewardship on farmland. Pages 103-120 in C. Bieling, and T. Plieninger, editors. The science and practice of landscape stewardship. Cambridge University Press, Cambridge, UK. https://doi.org/10.1017/9781316499016.011

Plieninger, T., T. Kizos, C. Bieling, L. Le Dû-Blayo, M.-A. Budniok, M. Bürgi, C. L. Crumley, G. Girod, P. Howard, J. Kolen, T. Kuemmerle, G. Milcinski, H. Palang, K. Trommler, and P. H. Verburg. 2015. Exploring ecosystem-change and society through a landscape lens: recent progress in European landscape research. Ecology and Society 20(2):5. http://doi.org/10.5751/ES-07443-200205

Plummer, R., B. Crona, D. R. Armitage, P. Olsson, M. Tengö, and O. Yudina. 2012. Adaptive comanagement: a systematic review and analysis. Ecology and Society 17(3):11. http://doi. org/10.5751/ES-04952-170311

Poteete, A. R., M. A. Janssen, and E. Ostrom. 2010. Working together: collective action, the commons, and multiple methods in practice. Princeton University Press, Princeton, New Jersey, USA. https://doi.org/10.1515/9781400835157

Prager, K., M. Reed, and A. Scott. 2012. Encouraging collaboration for the provision of ecosystem services at a landscape scale-rethinking agri-environmental payments. Land Use Policy 29(1):244-249. http://doi.org/10.1016/j.landusepol.2011.06.012

Pretty, J., and D. Smith. 2004. Social capital in biodiversity conservation and management. Conservation Biology 18 (3):631-638. http://doi.org/10.1111/j.1523-1739.2004.00126.x

QSR International. 2017. Nvivo 11 for Windows. Pro edition. QSR International, Melbourne, Australia.

Rebelo, A. J., D. C. le Maitre, K. Esler, and R. Cowling. 2013. Are we destroying our insurance policy? The effects of alien invasion and subsequent restoration: a case study of the Kromme River system, South Africa. Pages 335-364 in B. Fu and B. K. Jones, editors. Landscape ecology for sustainable environment and culture. Springer Science+Business Media, Dordrecht, The Netherlands.

Ross, R. 1997. The Kat River rebellion and Khoikhoi nationalism: the fate of an ethnic identification. Kronos 24:91-105.

Sadler, G. R., H.-C. Lee, R. S.-H. Lim, and J. Fullerton. 2010. Research article: recruitment of hard-to-reach population 
subgroups via adaptations of the snowball sampling strategy. Nursing and Health Sciences 12(3):369-374. http://doi. org/10.1111/j.1442-2018.2010.00541.x

Sandström, C. 2009. Institutional dimensions of comanagement: participation, power, and process. Society and Natural Resources 22(3):230-244. https://doi.org/10.1080/08941920802183354

Saunders, F. P. 2014. The promise of common pool resource theory and the reality of commons projects. International Journal of the Commons 8(2):636-656. https://doi.org/10.18352/ijc.477

Sayer, J., T. Sunderland, J. Ghazoul, J.-L. Pfund, D. Sheil, E. Meijaard, M. Venter, A. K. Boedhihartono, M. Day, C. Garcia, C. van Oosten, and L. E. Buck. 2013. Ten principles for a landscape approach to econciling agriculture, conservation, and other competing land uses. Proceedings of the National Academy of Sciences 110(21):8349-8356. http://doi.org/10.1073/pnas.1210595110

Schafer, P. 2014. The peaks and troughs of Langkloof land reform. Finweek 11 September 2014:22-25. [online] URL: https:// www.pressreader.com/south-africa/finweek-englishedition/20140911/281779922314165

Steffen, W., Å. Persson, L. Deutsch, J. Zalasiewicz, M. Williams, K. Richardson, C. Crumley, P. Crutzen, C. Folke, L. Gordon, M. Molina, V. Ramanathan, J. Rockström, M. Scheffer, H. Schellnhuber, and U. Svedin. 2011. The Anthropocene: from global change to planetary stewardship. AMBIO 40(7):739-761. http://doi.org/10.1007/s13280-011-0185-X

Swiegers, J. J. 1994. Die Geskiedenis Van Die Langkloof Tot 1795. Thesis. University of Stellenbosch, Stellenbosch, South Africa. [online] URL: http://scholar.sun.ac.za/handle/10019.1/58336

Talbot, M. 2012. Improving Algoa's water security through restoration, sustainable land uses and investments in ecosystem services (IES): action plan. GIZ Mpumalanga Rural Development Programme (MRDP) and Living Lands, Cape Town, South Africa.

van de Witte, Y. 2015. Kouga catchment: towards a clearing strategy for Black Wattle. Internal report. Living Lands, Cape Town, South Africa.

van Huyssteen, A. 2008. Die Storie Van Langkloof. DANISTA, Melkbosstrand, Cape Town.

Veerkamp, C. 2013. Agriculture and biodiversity conservation in the South African water-stressed Kouga catchment: an inventory and integrated assessment relating landmanagement and ecosystem services. Thesis. Wageningen University, Wageningen, The Netherlands.

Weber, E. P., J. M. Belsky, D. Lach, and A. S. Cheng. 2014. The value of practice-based knowledge. Society and Natural Resources 27(10):1074-1088. http://doi.org/10.1080/08941920.2014.919168

Welchman, J. 2012. A defence of environmental stewardship. Environmental Values 21(3):297-316. http://dx.doi. org/10.3197/096327112X13400390125975

Wollenberg, E., C. López, and J. Anderson. 2005. Though all things differ: pluralism as a basis for cooperation in forests. CIFOR, Bogor, Indonesia. http://dx.doi.org/10.17528/cifor/001805
Wondolleck, J. M., and S. L. Yaffee. 2000. Making collaboration work: lessons from innovation in natural resource management. Island, Washington, D.C., USA.

Yin, R. K. 2009. Case study research: design and methods. Sage, Thousand Oaks, California, USA.

Zachrisson, A., and K. Beland Lindahl. 2013. Conflict resolution through collaboration: preconditions and limitations in forest and nature conservation controversies. Forest Policy and Economics 33:39-46. https://doi.org/10.1016/j.forpol.2013.04.008 
Appendix 1: Interview guide for face-to-face, semi-structured interviews conducted with landscape stakeholders.

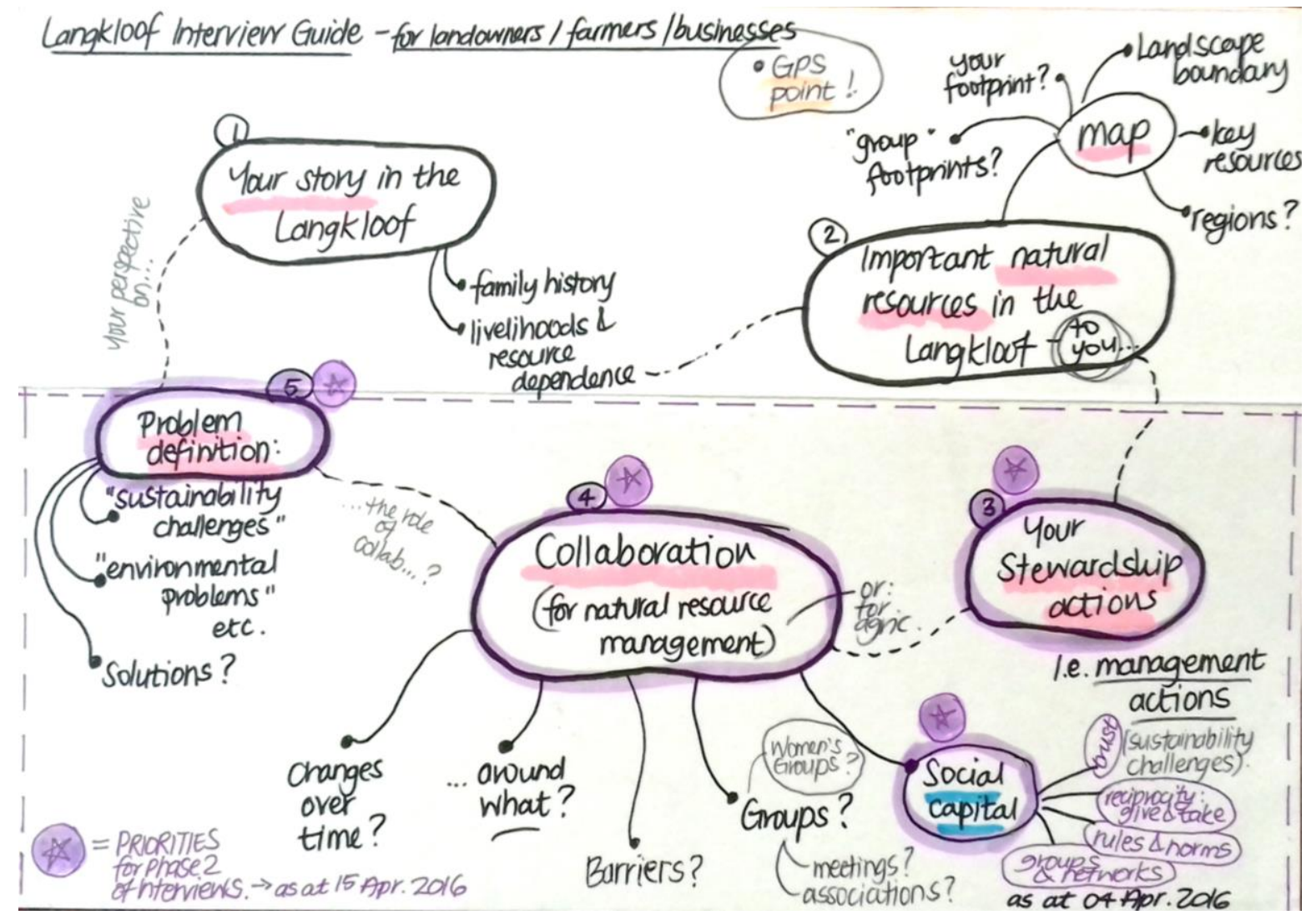

